\title{
Ajaran Minardi Mursyid dan Korelasinya dengan Aliran Sesat di Indonesia
}

\author{
Irma Rumtianing U.H. \\ STAIN Ponorogo
}

\begin{abstract}
Along with the surge of "religious" studies, we apparently have to be selective in attending it, because nowadays many people who attending the Islamic study feel worry about what is delivered by the religious teacher, which is considered as "ingkar sunnah", that is, abandoning the prophet's hadits, in the explanation of his speech. Similar to what Minardi Mursyid from Surakarta did about his lesson on hadits which has ruined up and spoiled the principles of Islamic aqidah. The investigation of the Fatwa Team of Indonesian Ulema Council (MUI) of Surakarta on Minardi Mursyid's lesson and the LPPA Tauhid activities found out that Minardi Mursyid's lesson is similar to the ingkar sunnah sect which has been declared as deviant by MUI and their activities are prohibited by the government.
\end{abstract}

Keywords: inkar as-sunnah, deviant sect, Minardi Mursyid’s lesson

\begin{abstract}
Abstrak
Seiring dengan maraknya gelaran kajian-kajian "agama", kiranya kita tetap harus selektif dalam mengikutinya, karena kini tidak sedikit para jamaah yang hadir dalam sebuah kajian tersebut sudah mulai merasa resah dengan apa yang disampaikan oleh beberapa narasumber yang disinyalir "Inkar Sunnah/ menafikan hadits Rasulullah Saw." dalam paparan kajiannya. Seperti yang dilakukan oleh Minardi Mursyid dari Surakarta mengenai ajaranya tentang hadits yang telah merusak sendi-sendi aqidah Islam dan menodainya. Kajian tim fatwa MUI Surakarta terhadap ajaran Minardi Mursyid dan kegiatan LPPA Tauhid menyimpulkan, bahwa ajaran Minardi Mursyid serupa dengan aliran ingkar sunah yang telah difatwakan sesat oleh MUI dan dilarang kegiatannya oleh pemerintah.
\end{abstract}

Kata Kunci: Inkar as-sunnah, aliran sesat, Ajaran Minardi Mursyid 


\section{Pendahuluan}

Bagi umat Islam, as-sunnah merupakan salah satu sumber hukum penting kedua setelah Alqur'an. Namun ada kelompok umat muslim yang tidak mau menggunakannya sebagai sumber hukum. Kelompok itu biasa disebut kelompok inkar as-sunnah. Inkar alSunnah dapat diartikan sebagai suatu nama atau aliran atau suatu paham keagamaan dalam masyarakat Islam yang menolak atau mengingkari sunnah untuk dijadikan sebagai sumber dasar tasyri'. Menurut Daud Rasyid Inkar as-sunnah adalah sebuah sikap penolakan terhadap sunnah Rasul, baik sebagian maupun seluruhnya“. Secara bahasa pengertian hadits dan sunnah sendiri terjadi perbedaan pendapat dikalangan para ulama, ada yang menyamakan keduanya dan ada yang membedakan. Pengertian keduanya akan disamakan seperti pendapat para muhaditsin, yaitu suatu perkataan, perbuatan, taqrir dan sifat Rasulullah Saw (Daud Rasyid 2006).

Kata "Inkar Sunnah" dimaksudkan untuk menunjukkan gerakan atau paham yang timbul dalam masyarakat islam yang menolak hadits atau sunnah sebagai sumber kedua hukum Islam. Menurutnya inkar as-sunnah tidak semata-mata penolakan total terhadap sunnah, penolakan terhadap sebagian sunnah pun termasuk inkar as- sunnah.

Seiring dengan maraknya gelaran kajian-kajian ilmu yang berkembang dimasyarakat,, layaklah kiranya kita tetap harus selektif dalam mengikutinya, karena kini tidak sedikit para jamaah yang hadir dalam kajian-kajian tersebut sudah mulai merasa resah dengan apa yang disampaikan oleh beberapa narasumber yang disinyalir "Inkar Sunnah/ menafikan hadits Rasulullah Saw." dalam paparan kajiannya. Seperti yang dilakukan oleh Minardi Mursyid dari Surakarta mengenai ajaranya tentang hadits yang telah merusak sendi-sendi aqidah Islam dan menodainya, diantaranya menulis buku berjudul : 1). A1-Qur'an sebagai Rahmatan lil 'Alamin. 2). Benarkah mendalami Al-Qur'an itu Inkar As-Sunnah dan 3). menulis artikel tentang "bimbingan shalat tahajud".

Kajian tim fatwa MUI Surakarta terhadap ajaran Minardi Mursyid dan kegiatan LPPA Tauhid menyimpulkan, bahwa ajaran Minardi Mursyid serupa dengan aliran ingkar sunah yang telah difatwakan sesat oleh MUI dan dilarang kegiatannya oleh pemerintah. Mengingat hal tersebut, perlu dicermati lebih lanjut tentang bentuk-bentuk ajaran Minardi Mursyid sehingga oleh MUI di klaim sebagai ajaran inkar as-sunnah. Perlu pula dikaji lebih lanjut tentang korelasi aliran inkar as-sunnah dengan aliran sesat di Indonesia, sehingga di larang untuk diajarkan kepada masyarakat.

\section{Ajaran Minardi Mursyid Pada Kegiatan LPP Tauhid/Yatain.}

Inkar as-sunnah adalah sebuah sikap penolakan terhadap sunnah Rasul baik sebagian maupun seluruhya. Mereka membuat metodologi tertentu dalam menyikapi sunnah. Hal ini 
mengakibatkan tertolaknya sunnah, baik sebagian maupun seluruhnya. (Daud Rasyid 2006).

Terdiri dari dua kata yaitu "Inkar" dan "Sunnah". Inkar, menurut bahasa, artinya "menolak atau mengingkari", berasal dari kata kerja, ankara-yunkiru. Sedangkan Sunnah, menurut bahasa mempunyai beberapa arti diantaranya adalah, "jalan yang dijalani, terpuji atau tidak," suatu tradisi yang sudah dibiasakan dinamai sunnah, meskipun tidak baik. Secara definitif Inkar al-Sunnah dapat ddiartikan sebagai suatu nama atau aliran atau suatu paham keagamaan dalam masyarakat Islam yang menolak atau mengingkari Sunnah untuk dijadikan sebagai sumber san dasar syariat Islam. Inkar as-sunnah adalah sebuah sikap penolakan terhadap sunnah Rasul, baik sebagian maupun seluruhnya. Secara bahasa pengertian hadits dan sunnah sendiri terjadi perbedaan dikalangan para ulama, ada yang menyamakan keduanya dan ada yang membedakan. Pengertian keduanya akan disamakan seperti pendapat para muhaditsin, yaitu suatu perkataan, perbuatan, taqrir dan sifat Rasulullah Saw (Daud Rasyid 2006).

Paham Inkar Sunah muncul di Indonesia secara terang-terangan kira-kira terjadi pada tahun 1980-an. Persisnya menurut Zufran Rahman (seorang peneliti pemikiran Ingkar Sunah dan Dosen IAIN Jambi) pada tahun 1982-1983 (Zufran Rahman 1995). Tetapi bukti menunjukkan, bahwa pada 1981 paham ini sudah ada, seperti yang terjadi di Bogor pimpinan oleh H. Endi Suradi dan 1982 aliran sesat yang diajarkan H. Sanwani asal kelahiran Pasar Rumput itu sudah berlangsung sejak November 1982 (Amin Jamaluddin 1988). Kemungkinan besar jauh sebelum itu sudah ada penyebarannya secara sembunyi-sembunyi seperti yang dilakukan oleh orientalis di Indonesia Snouck Hourgronje. Buku-buku orientalis atau kaki tangannya sudah bertebaran jauh sebelumnya.

Diantara paham inkar as-sunnah yang belakangan muncul adalah ajaran Minardi Mursyid dalam kegiatan pengajian LPP Tauhid atau Yatain (Yayasan Tauhid Indonesia) yang berasal dari kota Surakarta. Mbah Min (sapaan akrap Minardi Mursyid) menulis makalah yang berjudul "Masyarakat Manusia di Planet Luar Bumi” dari awal sampai akhir maka tidak satupun kita menemukan kutipan hadits di sana. Jika makalah ini dibaca oleh orang awam bisa menyesatkan karena mbah Min (panggilan akrab Minardi) mengemasnya dengan bumbu logika. Makalah tersebut berjumlah 25 halaman (58.025 karakter), semuanya memakai ayatayat al-Qur'an sebagai dalil.

Makalah tersebut diawali dengan cercaan mbah Min atas kelambatan umat Islam dalam merespon setiap perkembangan teknologi. Umat Islam banyak yang hanya jadi penonton atas perkembangan teknologi yang ada. Tampak jelas di makalah tersebut (dan juga dalam ceramah-ceramahnya) mbah Min menyesalkan umat Islam yang masih saja menyitir ucapan Imam al-Bukhari dan ulama-ulama "kuno" lainnya karena kehidupan mereka jauh setelah Nabi meninggal. Ia ingin mengajak umat Islam untuk memakai akal pikirannya sendiri dan 
tidak terpengaruh oleh doktrin-doktrin lama. Ia mengatakan:

"Sebenarnya sejak 15 abad yang lalu Al Qur'an telah menerangkan berbagai persoalan yang ada di jagad raya ini, cuma masalahnya sistem pendidikan yang selama ini diajarkan hanyalah berupa hafalan-hafalan sehingga pada umumnya anak didik kita banyak yang tidak bisa memahami tentang sesuatu. Seringkali orang dipaksa untuk percaya begitu saja secara taklid buta walaupun kadangkadang keterangan yang disampaikan tidak sejalan dengan pemikiran secara wajar. Ironisnya para Sarjana kitapun masih banyak yang kurang kritis dan teliti, bahkan mereka juga mengikuti pemahaman ratusan atau bahkan ribuan tahun yang lalu, sehingga posisi kita sering selalu ketinggalan, terutama dalam hal Ilmu Pengetahuan dan Teknologi."

Makalah tersebut diawali dengan pembahasan tentang dunia, sama'/samawat dan dabbah. Kesesatan pertama langsung tampak pada saat ia membahas tentang dunia. Ia menyitir al-Qur'an surat al-Mulk ayat 5 sebagai berikut:

"Sesungguhnya kami telah menghiasi langit yang dekat dengan bintang-bintang dan Kami jadikan bintang-bintang itu alat pelempar setan. Dan Kami sediakan mereka siksa Neraka yang menyela-nyala”

Inilah yang aneh, meski mbah Min menampilkan terjemahan dari tiga versi yakni dari Departemen Agama, Lembaga Percetakan Al Qur'an Raja Fahd di Madinah al Munawarah, dan terjemahan Prof. Mahmud Yunus, tetapi mbah Min menolak ketiga model terjemahan tersebut. Ia dengan sombongnya menerjemahkan sendiri ayat tersebut dengan akalnya. Berikut terjemahan versi mbah Min:

"Dan sungguh Kami hiasi ANGKASA DUNIA = angkasanya semesta raya (langitnya semesta raya ini) dengan bintang-bintang (pelita-pelita) dan Kami jadikan dia (bintang-bintang itu) ancaman (rujuman) bagi setan-setan. Dan kami sediakan atas mereka siksa yang membakar".

Selanjutnya mbah Min mengatakan: "Jika "sama'a dunya" diartikan dengan "langit yang dekat dengan Bumi" atau "langit yang hampir ke dunia" maka langit manakah yang jauh dari dunia, atau bahkan pengertian dunia seolah-olah hanyalah Bumi ini. Maka semestinya dia harus diartikan "angkasa dunia", dia adalah angkasanya atau langitnya semesta raya ini dan bukan hanya langitnya Bumi."

Mbah Min ingin menegaskan bahwa langit yang ada adalah langitnya semesta alam, bukan hanya langitnya bumi. Di bagian lain mbah Min memahami bahwa langit yang dimaksud adalah seperti "longan" (kolong di bawah ranjang) yang tidak pernah diciptakan. Ia ada dengan sendirinya karena adanya bumi, sebagaimana longan yang ada karena adanya ranjang. Begitu bumi hilang, maka langit pun hilang. Sebagaimana jika ranjang hilang, maka hilanglah longan. Pemahaman ini muncul barangkali mbah Min belum pernah membaca surat al-Baqarah ayat 29 bahwa langit itu diciptakan oleh Allah. 
"Dia-lah Allah, yang menjadikan segala yang ada di bumi untuk kamu dan Dia berkehendak (menciptakan) langit, lalu dijadikan-Nya tujuh langit. Dan Dia Maha Mengetahui segala sesuatu." (Q.S. Al-Baqarah: 29).

Atau ayat sebelumnya yang menyatakan bahwa langit itu dijadikan Allah sebagai atap bagi manusia.

"Dialah yang menjadikan bumi sebagai hamparan bagimu dan langit sebagai atap, dan Dia menurunkan air (hujan) dari langit, lalu Dia menghasilkan dengan hujan itu segala buah-buahan sebagai rezki untukmu; karena itu janganlah kamu mengadakan sekutu-sekutu bagi Alloh, padahal kamu mengetahui." (Q.S. AlBaqarah: 22).

Dari ayat ini jelaslah bahwa langit bukanlah "longan" sebagaimana kata mbah Min. Bagaimana mungkin "longan" bisa menjadi atap, apalagi bisa mengeluarkan air hujan. Dan di ayat lain dijelaskan pula bahwa langit pun bisa pecah saat hari kiamat datang (77:9; 82:1; 84:1). Langit pun mempunyai pintu-pintu (78:19). Jika langit dikatakan seperti longan, bagaimana mungkin ia bisa terbelah dan memiliki pintu.

Mbah Min juga mempertanyakan arti "rujuman lis syayâthin" yang diartikan sebagai pelempar syetan. Mbah Min mengartikannya sebagai ancaman bagi para syetan, bukan sebagai alat pelempar, Ia mengatakan:

"Kapan Allah pernah melempar setan dengan bintang yang sangat besar itu?

Padahal keadaan bintang itu sama dengan Surya (Matahari) kita, maka setan mana yang dilempar dengan benda sebesar itu."

Tampak jelas bahwa ia sama sekali tidak mendahulukan iman daripada logika. Mestinya iman tidak boleh dikalahkan oleh logika. Sebagaimana peristiwa Isra' Mi'raj Nabi yang dipertanyakan oleh Mbah Min dan orang-orang inkarus sunnah kebanyakan. Kita mestinya mencontoh sikap sahabat Abu Bakar r.a yang dengan lantang mengatakan:

"Kalau itu (peristiwa Isra' Mi'raj) yang mengatakan adalah Nabi, maka saya pasti percaya"

Dengan sikapnya itulah maka tidak berlebihan jika Rasulullah memberinya gelar ashShiddieq. Karena Abu Bakar telah mendahulukan imannya daripada akalnya. Meskipun barangkali akalnya tidak bisa mencerna peristiwa Isra' Mi'raj, tapi beliau tetap beriman dengan peristiwa itu, sebab Nabi tidak pernah berbohong. Bagaimana mungkin seseorang yang selama 40 tahun saja tidak pernah berbohong kepada manusia, kemudian ia berbohong atas nama Allah.

Penafsiran "rujuman lis syayatin" sebagai pelempar syetan sudah menjadi kesepakatan ulama. Di dalam tafsir at-Thabary dijelaskan bahwa fungsi bintang itu ada tiga: sebagai penghias langit, sebagai pelempar syetan, dan sebagai alat untuk penanda arah. Di dalam surat al-Jin: 8 juga dijelaskan tentang penggunaan bintang sebagai pelempar syetan. Yakni para syetan yang mencoba mencuri informasi dari langit. Sebagaimana terdapat dalam surat 
al Jin ayat 8-9 yang artinya:

"Dan sesungguhnya kami telah mencoba mengetahui (rahasia) langit, maka kami mendapatinya penuh dengan penjagaan yang kuat dan panah-panah api. Dan sesungguhnya kami dahulu dapat menduduki beberapa tempat di langit itu untuk mendengar-dengarkan (berita-beritanya). Tetapi sekarang barangsiapa yang (mencoba) mendengar-dengarkan (seperti itu) tentu akan menjumpai panah api yang mengintai (untuk membakarnya)." (Q.S. Jin: 8-9)

Jadi jelaslah sudah bahwa selain sebagai hiasan dan alat penanda arah mata angin, bintang juga berfungsi sebagai alat untuk melempar para syetan yang mencoba mencuri informasi dari langit. Jadi apa yang dikatakan oleh mbah Min adalah pengawuran yang luarbiasa.

Pembahasan kedua yang dilakukan oleh mbah Min adalah tentang sama'samawat. Dalam pembahasan ini kembali mbah Min mengutarakan tafsiranya. Dia menerjemahkan lafal sama' dengan semaunya sendiri. Terkadang sama' diartikan sebagai atmosfir, terkadang diartikan sebagai tata surya, terkadang diartikan planet-planet, dan terkadang diartikan sebagai langit.

Penafsiran yang tidak konsisten tentang lafal sama'/samawat ini terjadi karena sejak awal mbah Min sudah tidak percaya dengan langit. Seperti yang sudah dijelaskan di depan bahwa langit menurut mbah Min adalah "longan" yang meliputi setiap planet yang ada. Dimana ada planet maka di situ juga ada langit. Sehingga untuk mendukung argumennya ini ia memaksakan tafsiran sama'/samawat dengan berbagai arti.

Lebih lanjut mbah Min juga tidak percaya akan adanya langit lapis tujuh. Kalau memang langit lapis tujuh itu ada, mengapa sampai sekarang belum juga ditemukan? Begitu argumen yang ia utarakan.

Yang lebih lucu lagi adalah ketika mbah Min mengartikan Q.S. Nuh ayat 16, tampak sekali bahwa mbah Min ini memang tidak paham tata bahasa Arab, sehingga ia keliru dalam mengartikan lafal fihinna. Kata fihinna adalah dlomir yang kembali kepada samawat, tetapi oleh mbah Min diartikan sebagai bulan-bulan. Perhatikan uraian ngawurnya berikut:

"Kalau kita perhatikan pada Surat Nuh ayat 15 dinyatakan bahwa Allah telah menciptakan tujuh Samawat itu bertingkat-tingkat. Memang keadaan planetplanet itu bertingkat-tingkat menurut garis orbitnya masing-masing. Kemudian pada ayat 16 dinyatakan DIA jadikan BULAN-BULAN padanya (fiihinna) berarti Bulannya banyak, padahal Bulan yang ada di Bumi ini hanyalah satu. Maka Bulan yang lain adalah Bulan dari masing-masing planet itu, karena tidak mungkin langit memiliki Bulan atau dikitari Bulan, karena itu yang dikitari Bulan pastilah planet-planet itu" .

Mbah Min juga mempertanyakan tafsiran Q.S. An-Naba' ayat 12, bahwa Allah menciptakan tujuh yang kokoh. Menurut mbah Min, jelaslah sudah bahwa yang dimaksud 
tujuh yang kokoh bukanlah langit, melainkan planet seperti bumi ini. Sedangkan langit tidak mungkin kokoh.

Padahal al-Qur'an sendiri menjelaskan bahwa Allah menciptakan langit tanpa tiang. Perhatikan ayat berikut:

"Dia menciptakan langit tanpa tiang yang kamu melihatnya dan Dia meletakkan gunung-gunung (di permukaan) bumi supaya bumi itu tidak menggoyangkan kamu; dan memperkembang biakkan padanya segala macam jenis binatang. Dan Kami turunkan air hujan dari langit, lalu Kami tumbuhkan padanya segala macam tumbuh-tumbuhan yang baik". (Q.S. Luqman: 10).

Pembahasan berikutnya adalah tentang dabbah. Menurut mbah Min penafsiran dabbah dengan binatang melata adalah salah. Menurutnya dabbah tidak hanya sekedar binatang, tetapi juga manusia. Dia mempertanyakan penerjemahan yang dilakukan oleh Departemen Agama pada surat asy-Syura ayat 29 sebagai berikut:

"Dan diantara Ayat-ayat (tanda-tanda kekuasaan)Nya ialah menciptakan langit dan Bumi dan makhluk-makhluk yang melata yang DIA sebarkan pada keduanya. Dan DIA maha kuasa mengumpulkan apabila dikehendakiNYA.”

Menurut mbah Min ayat tesebut sebaiknya berarti:

"Dan dari Ayat-ayat-Nya ialah penciptaan Samawat (planet-planet) dan Bumi, serta yang DIA kembang biakkan pada keduanya (Samawat dan Bumi) dari dabbah (makhluk berjiwa) dan DIA atas pengumpulan ketika DIA kehendaki adalah menentukan.”

Memang kalau kita baca tafsir Ibnu Katsir, maka arti dabbah itu meliputi malaikat, manusia, jin, dan hewan-hewan. Dalam hal ini mbah Min ada benarnya, tetapi tidak mutlak. Karena ia masih beranggapan bahwa bagaimana mungkin dabbah bisa hidup di langit. Kalau dabbah hidup di planet pasti bisa. Padahal ayat tersebut menyebutkan langit dan bumi. Jadi tidak hanya menyebutkan langit saja. Sudah pasti yang hidup di langit adalah para malaikat dan yang hidup di bumi adalah manusia, jin dan binatang melata.

Selain ajaran diatas, ajaran Minardi Mursyid tentang hadits juga telah merusak sendi sendi aqidah Islam dan menodainya, diantaranya :

a. Buku berjudul "Al Quran sebagai Rahmatan lil 'Alamin".

...Maka mestinya hadits yang paling benar adalah yang datang dari Allah yang berupa wahyu Al Quran, karena dia disampaikan oleh Nabi Muhammad secara langsung..... (halaman 94, butir b)

....Namun perlu disadari bahwa apa saja yang dilakukan Muhammad, selain Al Quran itu bukan wahyu, karena itu dia bukan hukum, karena hukum seutuhnya ada dalam Al Quran.... (halaman 97)

....Keterangan itu juga bisa dipahami bahwa sesungguhnya semua keterangan Nabi selain Al Quran bukanlah merupakan sumber hukum, buktinya Nabi melarang menulisnya. Kalau memang dia adalah sumber hukum tentulah 
tidak dilarang untuk ditulis, bahkan seharusnya ditulis.... (halaman 99)

...Dari wasiat Nabi seperti itu memberikan pengertian kepada kita bahwa sesungguhnya Al Quran itu sudah cukup sempurna untuk persoalan, karena Nabi Muhammad tahu persis semua kandungan Al Quran, sehingga tidak perlu adanya hukum pelengkap yang harus menyertai Al Quran karena memang $\mathrm{Al}$ Quran sudah lengkap.... (halaman 99)

b. Buku berjudul "Benarkah Mendalami Al Quran Itu Ingkar Sunnah?” Diantaranya Pengingkaran terhadap adanya azab kubur.

...Sebagaimana yang dikatakan: "Ilustrasi di bagian akhir tentang hadishadis yang mengangkat tentang siksa kubur yang mengerikan dan menakutkan itu pun perlu dikaji ulang agar orang tidak dihantui oleh cerita-cerita yang tidak jelas sumbernya, karena kalau diperhatikan dan diteliti menurut ayat Al Qur'an keterangan tentang siksa kubur itu tidak ada”...(halaman 123)

c. Makalah Minardi Mursyid yang berjudul "Bimbingan Untuk Bertahajud"

Dia memahami tahajud itu semedi, "Tahajud tidak sama dengan sholat, tetapi fokus bermeditasi khusus untuk Allah agar bisa terhubung dengan baik menuju Allohus Shomad (Alloh tujuan shamadi=semedi). maka kita bersemedi tujuannya hanya kepada Alloh saja. Diawali dengan tahajud, diharapkan akan bisa mencapai tingkat shamadi. Terlebih dahulu lakukan shalat dua rekaat (shalat malam), agar kalbu kita terhubung dengan Alloh. Setelah selesai shalat, duduklah dengan bersila atau sikap yang santai agar bisa bertahan lebih lama dan focus. Untuk lebih fokus pejamkan mata anda....pusatkan perhatian pada kalbu secara terus-menerus...dzikirlah pada Alloh secukupnya sampai beberapa saat dengan ayat-ayat berikut ini berulang-ulang”.

Selain buku dan makalah diatas Minardi Mursyid juga mengajarkan beberapa ajaranya, diantaranya adalah:

a. Minardi Mursyid dalam menerjemahkan Al Qur'an tidak sesuai dengan kaidah kaidah bahasa Arab dan ilmu tafsir, seperti : kata "zaighun" Qur’an surat Ali Imron ayat 7 yang artinya sesat atau kesesatan, dia artikan dengan "inisiatif”. Sebagaimana yang dia ungkapkan "adapun orang yang dalam qoabunya condong (inisiatif)" (Terjemahan Al Qur'an versi Tadabbur : Terbitan LPPA Tauhid 2007 oleh Minardi Mursyid)

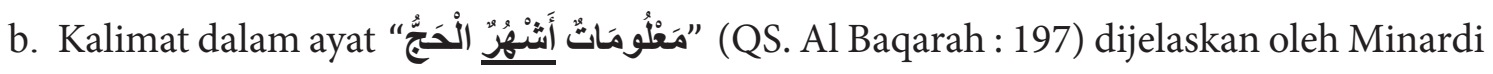
Mursyid bahwa "Haji itu pada bulan-bulan tertentu yaitu, Muharram, Rajab, Zulqa’dah dan Dzulhijjah"

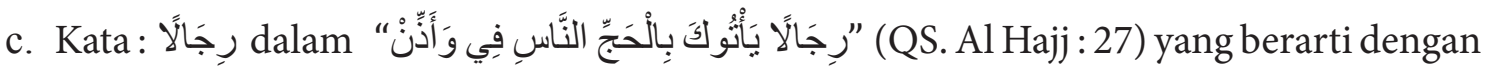
berjalan kaki, dia artikan dengan "berlaki-laki" (Terjemahan Al Qur'an versi Tadabbur : Terbitan LPPA Tauhid 2007 oleh Minardi Mursyid)

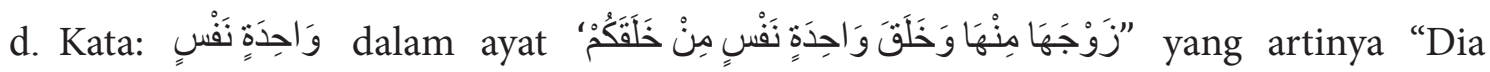


menciptakan kalian dari diri yang satu (Adam) dan Dia ciptakan darinya isterinya (Hawa), ditafsirkan oleh Minardi Mursyid bahwa manusia pertama adalah wanita. (Terjemahan Al Qur'an versi Tadabbur : Terbitan LPPA Tauhid 2007 oleh Minardi Mursyid).

Selain hal-hal diatas, masih banyak lagi keganjilan mbah Min dalam menafsirkan ayatayat Al Qur'an. Minardi Mursyid mengajarkan bahwa sumber hukum Islam itu hanya Al Qur’an, karena selain Al Qur'an bukan wahyu (Al Qur'an sebagai Rahmatan Lil Alamin: hal 97 No. 4).

Dari paparan tentang ajaran-ajaran Minardi Mursyid tersebut diatas bisa kita tarik benang merah bahwa ajaran mbah Min termasuk ajaran kelompok inkar as-sunnah.Salah satu ciri dari kelompok inkar as-sunnah adalah tidak menggunakan al-hadits sebagai bayan dari al-Qur'an dalam menafsirkan ayat al-Qur'an. Tetapi menggunakan akalnya sendiri, sehingga boleh jadi akan terjadi beragam penafsiran yang sifatnya subyektif sesuai keinginan masing-masing penafsir. Sebagai contoh dalam pelaksanaan ibadah haji, mbah Min berpendapat bahwa haji boleh dikerjakan pada waktu 4 bulan haram yaitu: Zulqaidah, Zulhijah, Muharram, dan Rajab. Alasannya. haji itu dijamin oleh Allah keamanannya. Kalau orang datang berkumpul semua pada bulan Dzulhijah saja untuk mengerjakan haji, itu bukan keamanan lagi namanya. Sebab ada yang terinjak-injak sampai babak belur, ada yang patah kaki dan sebagainya. Kalau sudah begitu tidak di jamin oleh Allah lagi namanya. Karena itu kalau terlalu ramai atau terlalu panas pada bulan dzulhijah maka haji boleh dilaksanakan pada bulan muharram.

\section{Korelasi Ajaran Minardi Mursyid dengan Aliran Sesat}

Dalam Islam, standar untuk menetapkan kebenaran adalah dengan menggunakan alQur’an, al-Sunnah, Rukun Iman dan Rukun Islam. al-Qur'an merupakan kitab yang: pertama, tidak ada keraguan walaupun berbeda faham dalam penafsiranya, namun semuanya tidak meragukan kebenaran al-Qur'an. Bagi orang yang beriman dan bertaqwa, mereka tidak meragukan al-Qur'an. Hanya orang-orang kafir, musyrik dan fasik saja yang meragukan alQur'an. (Muhammad Umar Jiau Al-Haq 2009)

Kedua, Tidak ada kekeliruan. Hanya orang kafir, musyrik dan mnafik yang meragukan al-Qur'an. Mereka menuduh Nabi Muhammad Saw. yang membuat dan mengarangnya, sehingga banyak kekeliruan didalamnya. Ada juga sebagian kaum muslimin yang meragukan kebenaran al-Qur'an, terutama orang-orang yang telah terpengaruh oleh ajaran agama lain atau filsafat yang mereka pelajari.

Ketiga, dijamin kemurnianya. Sebagai Kitabullah, kata al-kitab berasal dari kata kataba atau kutiba yang artinya menulis atau ditulis. Sesuatu yang ditulis kemudian dijadikan aturan, 
disebut undang-undang. Al-Qur'an adalah undang-undang yang diturunkan oleh Yang Maha Pencipta, Maha Pengatur yaitu Allah SWT. Al-Qur'an adalah undang-undanguntuk mengatur hidup dan kehidupan manusia di dunia. Suatu al-Kitab harus dijamin kesahihan dan kemurnianya, karena merupakan kepastian yang harus diyakini kebenaranya. Al-Qur’an adalah satu-satunya kitab yang dijamin kemurnianya, sebagaimana terdapat dalam Surat alhijr ayat 9: "Sesungguhnya Kami-lah yang menurunkan al-Qur'an dan sesungguhnya Kami benar-benar memeliharanya".

Keempat, tidak ada pertentangan. Al-Qur'an adalah wahyu Allah sejak Nabi Adam as hingga Nabi Muhammad Saw. Wahyu yang diturunkan kepada Nabi Musa as (al-Taurat) dan Nabi Isa as (al-Injil), ditulis kembali dalam al-Qur'an. Apabila ada nasakh-mansukh dalam al-Qur'an hanyalah masalah hukum yang pelaksanaanya disesuaikan dengan kebutuhan pada masanya.

Apabila memahami al-Qur’an berdasarkan petunjuk Allah, niscaya tidak mungkin ada perbedaan pemahaman sehingga menimbulkan perbedan yang menghasilkan kelompokkelompok kaum muslim. Hanya orang-orang musyrik sajalah yang menjadikan Islam berpecah-pecah. Jadi apabila kaum muslimin kembali kepada al-Qur'an dengan penuh keikhlasan oleh hal-hal lain, maka perpecahan umat tidak mungkin akan terjadi.

Selanjutnya, standar untuk menetapkan kebenaran adalah as-Sunnah. Sunnah adalah perkataan, perbuatan serta ketetapan Nabi Saw., maka dapat dijelaskan sebabagai berikut: Pertama, sunnah qauliyah adalah perkataan Nabi Muhammad Saw. yang didasari oleh wahyu Allah. Tidak semua perkataan Nabi Saw.adalah sunnah . Perkataan yang tidak didasarkan wahyu Allah bukanlah al-sunnah. Misalnya, ketika beliau mengatakan bahwa madu adalah "haram", atau beliau mengatakan Zaid anak angkatnya adalah anak beliau. Perkataan bukanlah sunnah, karena Allah menegurnya. Rasulullah mengharamkan madu karena untuk menyenangkan hati para isterinya. Menjadikan Zaid sebagai anaknya, karena sifat kemanusiaanya. Hal ini wajar, karena beliau adalah manusia biasa yang mencintai isterinya dan mempunyai selera, sama dengan manusia lainya. Dari penjelasan tadi dapat dipahami sunnah qauliyah adalah perkataan atau ucapan Nabi Saw. sebagai Rasulullah dalam menjabarkan atau menjelaskan al-Qur'an.

Kedua, sunnah af'aliyah, yaitu perbuatan atau tindakan Nabi yang berdasarkan wahyu. Perbuatan tersebut dalam rangka melaksanakan tugas, fungsi dan kewajibanya sebagai Rasulullah. Bukanlah disebut sunnah apabila perbuatan beliau didasari karena tabiat atau kebiasaan sebagai bangsa arab. Misalnya kebiasaan bangsa arab memakan kurma, berpakaian serban, berkendaraan onta, dan sebagainya. Karena perbuatan tersebut merupakan kebiasaan, tabiat atau adat sebagai orang Arab. Karena Abu Jahalpun berpakaian surban, gamis panjang, karena dia orang Arab. Tabiat beliau dalam cara berpakaian, cara 
makan dan sebagainya boleh di contoh, tapi bukan harus dijadikan kewajiban dan berhujjah. Berpakaian yang menjadi sunnah adalah menutup aurat, bersih, dan tidak berlebihan. Tabiat manusia ini bukanlah suatu yang menjadi ukuran apalagi suatu kewajiban yang harus diikuti, karena Allah menciptakan manusia bersuku-suku dan berbangsa-bangsa dengan tabiat yang berbeda-beda, dan itu adalah kehendak Allah. Perbedaan tabiat dipengaruhi oleh lingkungan alam, masyarakat dan keluarga. Misalnya orang dibesarkan di daerah kutub akan berbeda tabiatnya dengan orangt-orang yang dibesarkan di daerah pantai, dan seterusnya.

Sunnah af'aliyah adalah perjalanan Nabi Saw.bersama para sahabatnya dalam rangka melaksanakan tugas yang diembanya. Dalam al-Qur'an dijelaskan tentang tugas pokok, fungsi, kewajiban, usaha dan konsekwensi perjuanganya adalah: 1) misi Rasul yaitu menyeru manusia untuk beribadah kepada Allah dan menjauhi Thaghut. Adapun tugas Rasul adalah mendhahirkan atau mewujudkan agama Allah di muka bumi. Tugas pokok para Rasul adalahtugas pokok umat Islam, karena merupakan stariat pokok agama Allah. 2). Fungsi dan kewajiban Rasul adalah untuk melaksanakan dinnullah sebagai aturan dan undang-undang, maka Nabi diutus untuk menjadi syahid, mubasyir, nadzir, da'i dan sirajan munira. Kelima fungsi inilah yang akan diwariskan oleh Nabi kepada ulama. Ulama yang bertanggung jawab terbentuknya "masyarakat muslim" yang mandiri dan merdeka, Daulah Islamiyah bukan Ghulama (bidak) institusi al-Thaghut. 3) wewenang Rasul adalah untuk melaksanakan tugas, fungsi dan kewajibanya, maka Rasul mempunyai wewenang: (1) pemberi keputusan, (2) pemberi pengampunan, (3) pemberi legitimasi, pemberi keputusan perang dan damai, dan mengelola infaq atau harta.

Jadi sunnah af'aliyah merupakan perbuatan atau tindakan Nabi Muhammad sebagai Rasulullah dalam mewujudkan al-Qur’an. Bukan tingkah laku beliau sebagai bangsa Arab.

Ketiga, sunnah taqririyah merupakan penetapan, pengakuan atau persetujuan. Di kalangan sebagian kaum muslim, taqrir lebih dekenal dengan pengertian "diamnya" atau persetujuan Nabi terhadap tindakan sahabat. Sunnah taqririyah adalah ketetapan: (1) Nabi Muhammad sebagai Rasul. Rasul artinya utusan Allah. Nabi Muhammad sebagai Rasul adalah mandataris allah sebagai maliki an-Nas di muka bumi yang harus diikuti dan ditaati, mentaati Rasul berarti mentaati Allah. (2) Nabi Muhammad sebagai Ulil al-Amri, Kepala Negara. Nabi Muhammad diutus sebagai Rasul ke muka bumji untuk menzahirkan aturan Allah, sekaligus untuk menjabarkan dan memimpin pelaksanaan aturan (a-Din) Allah tersebut. Pemimpin pelaksanaan aturan atau urusan kehidupan adalah ulil amri atau pemerintah. Setiap pemerintah mempunyai aparatur, Rasulullah sebagai kepala Negara dan sahabat sebagai aparaturnya. Sebagai kepala Negara beliau mempunyai tugas untuk menyampaikan amanah kepada yang berhak menerimanya, menetapkan hukum dengan adil, dan memberi pengajaran kepada masyarakat. Untuk menjalankan aturan pemimpin harus memiliki ketetapan untuk dijadikan rujukan dalam tehnis pelaksanaan aturan. Ketetapanya 
bersifat contemporer, berlaku pada saat itu, karena disesuaikan dengan kondisi, situasi dan kebutuhan pada saat itu. Dan Allah memerintahkan kepada orang mukmin untuk mentaati para pemimpin/ulil amri mereka. Pada masa Khalifah al-Rasyidin, ketetapan ini dikenal dengan “ijma' shahaby” karena ketetapan tersebut didasarkan hasil musyawarah para sahabat di "Majlis syura". Taqrir Rasulullah atau ijma; sahabat dapat dijadikan rujukan saat itu, namun apabila dijadikan rujukan atau dasar hukum saat ini karena kasusnya sama, merupakan suatu keharusan. Tetapi jika tidak sesuai dengan kondisi saat ini maka tidak wajib diikuti. (3) Nabi Muhammad sebagai panglima perang. Selain sebagai kepala pemerintahan, Rasulullah juga sebagai panglima perang. Jadi as-Sunnah taqririyah bukanlah sekedar "diamnya” Rasulullah dalam suatu urusan. Namun lebih merupakan ketetapan Rasulullah yang berhubungan dengan tugas, fungsi dan kewajiban Rasul.

Hal ketiga untuk menentukan kebenaran adalah arkanul iman. Urutan arkanul iman adalah:

a. Iman kepada Allah, artinya menerima atau percaya kepada zat-Nya, sifat-Nya dan af'al-Nya.Aplikasi beriman kepada Allah adalah: pertama, beriman kepada Rububiyah Allah, yaitu (1) meyakini bahwa Allah sebagai pencipta, pemelihara dan pengurus alam semesta, sehingga dalam kehidupanya senantiasa untuk mengabdi kepada Allah semata. (2) meyakini bahwa Allah Yang Mahapengatur alam semesta, sehingga semua aktifitas kehidupanya siap diatur oleh Allah SWT. (3) meyakini bahwa Allah Yang Mahapendidik, sehingga ilmu yang diberkan Allah kepadanya hanya untuk mengabdikan kepada Allah semata. Kedua, Beriman kepada mulkiyyah Allah. Aplikasinya adalah (1) mengikuti dan mentaati, loyal kepada Allah dan rasul-Nya. (2) mentaati perintah aparatur, pemerintahan, institusi atau Negara yang berdasarkan kitab Allah. (3) Tunduk patuh melaksanakan aturan Allah dan rasul-Nya. Dan menolak segala aturan hukum yang dating dari selain Allah. (4) siap mencontoh dan meneladani perjalanan sunnahnya. Ketiga, beriman kepada uluhiyyah Allah yaitu tidak ada yang dicintai, ditakuti, tempat sandaran dan pegharapan, tidak ada yang berhak diminta, dan tidak ada ruku' dan sujud kecuali hanya kepada Allah SWT.

b. Iman kepada Malaikat Allah, beriman kepada malaikat dengan segala sifatnya merupakan kesempurnaan keimanan seorang mukmin. Malaikat adalah aparatur kerajaan Allah yang memiliki sifat-sifat senantiasa taat kepada Allah, memiliki kemampuan istimewa, bertugas menyampaikan wahyu, memiliki tugas masing-masing dan menjaga manusia. Aplikasi beriman kepada Malaikat adalah: pertama, menerima dan meyakini yang dibawa Malaikat Jibril yang disampaikan kepada Nabi Muhammad Saw.adalah wahyu Allah SWT. Kedua, menerima dan meyakini tugas yang diberikan Allah kepada para malaikat tersebut. Menolak atau kufur kepada malaikat sama dengan menolak atau kufur kepada Allah SWT. 
c. Iman kepada Kitab Allah, beriman kepada kitab Allah adalah menjadikan al-Qur'an sebagai petunjuk dan tidak meragukanya. Orang-orang yang menolak al-Qur'an sebagai petunjuk hidup adalah kaum kafir. Aplikasi dari iman kepada kitab Allah adalah menjadikan al-Qur'an sebagai petunjuk atau pedoman dalam kehidupan pribadi, keluarga dan bermasyarakat, menjadikan al-Qur'an sebagai sumber hukum dalam mengatur kehidupan di dunia, dan menjadikan al-Qur'an sebagai alat ukur untuk menilai suatu hal.

d. Iman kepada Rasulullah, beriman kepada Rasulullah adalah menerima dan meyakini bahwa Rasul adalah "mandataris" Allah di muka bumi. Mandataris adalah manusia yang mendapat mandate untuk melaksanakan aturan-Nya. Beriman kepada Rasulullah berarti menerima Rasul sebagai aparat Allah yang memiliki misi, tugas, fungsi, kewajiban dan wewenang untuk mewujudkan al-Qur'an. Aplikasi beriman kepada Rasulullah adalah: mengikutinya dalam rangka cinta kepada Allah, mentaatinya dalam rangka mentaati Allah sebagai Malik, menjadikan "sunnah"nya sebagai uswah dalam mewujudkan al-Qur'an sebagai firman Allah.

e. Iman kepada hari akhir, iman kepada hari akhir adalah ciri muttaqin, dan yang membedakan antara orang yang beriman dan tidak beriman adalah iman kepada hari akhir. Aplikasi beriman kepada hari akhir adalah: mempersiapkan bekal untuk kehidupan akhirat, memperbanyak amal shalih, amal yang bermanfaat untuk manusia dan sesuai dengan perintah Allah serta contoh Rasul-Nya.

f. Iman kepada taqdir Allah, taqdir adalah ketentuan atau ketetapan Allah yang baik maupun yang buruk. Manusia menjalani dan menempuh ketentuan Allah tersebut harus disertai usaha, karena ketentuan Allah tersebut tidak ada satupun manusia yang mengetahuinya. Aplikasi dari beriman kepada qadla' dan qadar adalah berusaha dengan sungguh-sungguh menjalani kehidupan di dunia dengan melaksanakan aturan Allah, dan menerima segala ketetapan Allah yang menimpa dirinya yang baik maupun yang buruk dan tidak menjadi putus asa terhadap rahmat Allah SWT.

Di samping tiga hal di atas, standar untuk menetapkan kebenaranan adalah rukun islam. Islam adalah sistem kehidupan sekaligus sistem nilai. Sebagai sistem kehidupan islam mengatur hubungan antar manusia: idiologi, sosial, politik, budaya, ekonomi, pertahanan dan keamanan, mengatur hubungan manusia dan lingkunganya. Sebagai sistem nilai islam terdiri dari lima ajaran pokok yaitu syahadatain, shalat, zakat, puasa dan haji.

Syahadat merupakan dua perjanjian atau dua persaksian. Pertama pernyataan 'laailaaha illa Allah" dan kedua pernyataan "Muhammad Rasullah". Kedua pernyataan tersebut menjadi perjanjiann manusia dengan Allah, dimana perjanjian ini pula yang menjadikan sebab seseorang dapat melaksanakan hukum-hukum Allah. 
Shalat dan zakat adalah syariat yang diperintahkan secara langsung kepada setiap muslim. Dua perintah tersebut hampir tak pernah terpisahkan dalam satu ayat. Karena dua kewajiban ini merupakan pilar pokok tegaknya islam. Orang yang meninggalkan kewajiban zakat sama halnya dengan meninggalkan shalat.

Sedangkan haji artinya secara harfiah adalah tujuan dan maksud. Secara istilah haji adalah syariat pokok dalam islam yang wajib dilaksanakan bagi yang mampu. Melaksanakan syari;at haji hakikatnya adalah memperingati kejadian yang dialami oleh Nabi Adam dab hawa, Nabi Ibrahim,Siti hajar dan Nabi Ismail.

Adapun perintah puasa adalah perintah yang harus dilaksanakan secara terstruktur dan sistematis, ada input, proses dan out-put. In-put puasa adalah orang yang beriman, yaitu orang yang diperintahkan melaksanakan puasa, proses dalam pembentukan pribadi muttaqin dengan melaksanakan puasa. Prosesnya terdiri dari (1) waktu pelaksanaan (satu bulan pada bulan ramadhan), (2) ketentuan dan aturan (menahan diri dari lapar, dahaga dan sex sejak terbit fajar hingga tenggalam matahari, (3) Tempat tidak dalam bepergian (4) kondisi sehat dan mapu. Sedangkan oup put dari puasa adalah hasil yang diperoleh dari proses, yaitu menjadi manusia yang bertaqwa.

Kelima sikap tersebut merupakan sikap orang-orang yang bertaqwa. Apabila puasa dilaksanakan, namun sikap-sikap ini tak pernah dimiliki maka orang tersebut dikategorikan "orang-orang sesat", karena puasanya tidak mencapai "tujuan" dan hanyalah "ritual" belaka hanya mendapatkan lapar dan haus.

Makalah mbah Min yang berjudul "Masyarakat Manusia di Planet Luar Bumi” dari awal sampai akhir, maka tidak satupun ditemukan kutipan hadits di sana. Jika makalah ini dibaca oleh orang awam,bisa menyesatkan karena ia mengemasnya dengan bumbu logika. Makalah tersebut berjumlah 25 halaman (58.025 karakter), dan semuanya memakai ayatayat al-Qur'an sebagai dalil. Dalam makalah tersebut mbah Min mencerca atas kelambatan umat Islam dalam merespon setiap perkembangan teknologi. Umat Islam banyak yang hanya jadi penonton atas perkembangan teknologi yang ada. Tampak jelas di makalah tersebut (dan juga dalam ceramah-ceramahnya) mbah Min menyesalkan umat Islam yang masih saja menyitir ucapan Imam al-Bukhari dan ulama-ulama "kuno" lainnya karena kehidupan mereka jauh setelah Nabi meninggal. Ia ingin mengajak umat Islam untuk memakai akal pikirannya sendiri dan tidak terpengaruh oleh doktrin-doktrin lama.

Dalam buku yang berjudul “Al-Qur'an sebagai Rahmatan Lil'alamin” mbah Min menyebutkan:

...Maka mestinya hadits yang paling benar adalah yang datang dari Allah yang berupa wahyu Al Quran, karena dia disampaikan oleh Nabi Muhammad secara langsung. (hlm. 94, butir b). Namun perlu disadari bahwa apa saja yang dilakukan Muhammad, selain Al Quran itu bukan wahyu, karena itu dia bukan 
hukum, karena hukum seutuhnya ada dalam Al Quran. (hlm. 97). Keterangan itu juga bisa dipahami bahwa sesungguhnya semua keterangan Nabi selain Al Quran bukanlah merupakan sumber hukum, buktinya Nabi melarang menulisnya. Kalau memang dia adalah sumber hukum tentulah tidak dilarang untuk ditulis, bahkan seharusnya ditulis. (hlm. 99). Dari wasiat Nabi seperti itu memberikan pengertian kepada kita bahwa sesungguhnya Al Quran itu sudah cukup sempurna untuk persoalan, karena Nabi Muhammad tahu persis semua kandungan Al Quran, sehingga tidak perlu adanya hukum pelengkap yang harus menyertai Al Quran karena memang Al Quran sudah lengkap. (hlm. 99)

Selanjutnya dalam buku yang berjudul "Benarkah Mendalami Al Quran Itu Ingkar Sunnah?” Diantaranya Pengingkaran terhadap adanya azab kubur. Lihat hal. 123 :

":Sebagaimana yang dikatakan: "Ilustrasi di bagian akhir tentang hadis-hadis yang mengangkat tentang siksa kubur yang mengerikan dan menakutkan itu pun perlu dikaji ulang agar orang tidak dihantui oleh cerita-cerita yang tidak jelas sumbernya, karena kalau diperhatikan dan diteliti menurut ayat Al Qur'an keterangan tentang siksa kubur itu tidak ada”.

Makalah Minardi Mursyid selanjutnya berjudul "Bimbingan Untuk Bertahajud”, Dia memahami tahajud itu semedi,

"Tahajud tidak sama dengan shalat, tetapi fokus bermeditasi khusus untuk Allah agar bisa terhubung dengan baik menuju Allahus Shamad (Allah tujuan shamadi=semedi).maka kita bersemedi tujuannya hanya kepada Alloh saja. Diawali dengan tahajud, diharapkan akan bisa mencapai tingkat shamadi. Terlebih dahulu lakukan shalat dua rekaat (shalat malam), agar kalbu kita terhubung dengan Alloh. Setelah selesai shalat, duduklah dengan bersila atau sikap yang santai agar bisa bertahan lebih lama dan focus. Untuk lebih fokus pejamkan mata anda....pusatkan perhatian pada kalbu secara terus-menerus... dzikirlah pada Allah secukupnya sampai beberapa saat dengan ayat-ayat berikut ini berulang-ulang".

Dalam menerjemahkan Al Qur'an mbah Min tidak sesuai dengan kaidah -kaidah bahasa Arab dan ilmu tafsir, seperti : kata "zaighun" Qur'an surat Ali Imron ayat 7 yang artinya sesat atau kesesatan, dia artikan dengan “inisiatif”. Sebagaimana yang dia ungkapkan "adapun orang yang dalam qolbunya condong (inisiatif)" (Terjemahan Al Quran versi Tadabbur : Terbitan LPPA Tauhid 2007 oleh Minardi Mursyid). Kalimat dalam ayat

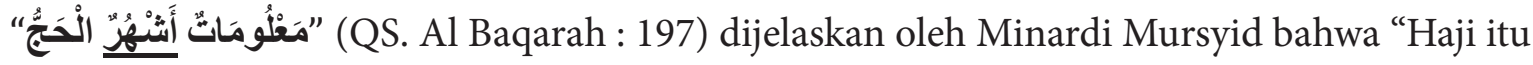
pada bulan-bulan tertentu yaitu, Muharram, Rajab, Zulqa'dah dan Dzulhijjah”. Kata : رِجَالَ

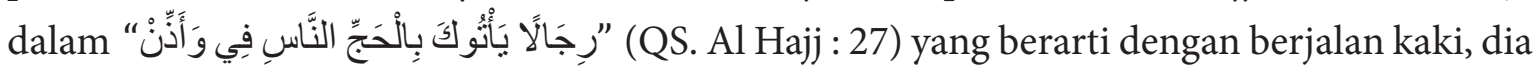
artikan dengan "berlaki-laki” (Terjemahan Al Qur’an versi Tadabbur : Terbitan LPPA Tauhid

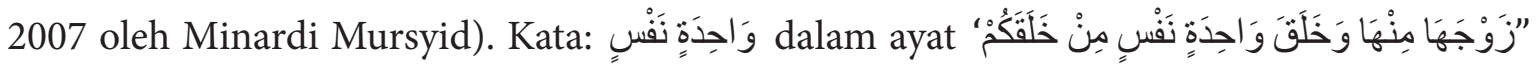
yang artinya "Dia menciptakan kalian dari diri yang satu (Adam) dan Dia ciptakan darinya isterinya (Hawa), ditafsirkan oleh Minardi Mursyid bahwa manusia pertama adalah wanita. (Terjemahan Al Qur'an versi Tadabbur : Terbitan LPPA Tauhid 2007 oleh Minardi Mursyid). 
Minardi Mursyid mengajarkan bahwa sumber hukum Islam itu hanya Al Qur'an, karena selain Al Qur’an bukan merupakan wahyu. Karena ajaran-ajaranya yang menyimpang tersebut maka bisa dikatakan ajaran Minardi Mursyid termasuk aliran sesat. Karena jika dianalisis dengan menggunakan standar ajaran yang benar yaitu menggunakan al-Qur’an, as-sunnah, rukun iman dan rukum islam, mbah Min sama sekali tidak menggunakanya. Minardi Mursyid hanya menggunakan al-Qur’an saja, itupun dengan sesuai penafsiran sendiri.

Kesesatan ajaran Minardi tersebut, juga bisa dibuktikan melalui konsep islam dalam memberantas kesesatan, yaitu: pertama, larangan mengangkat orang sesat sebagai pemimpin, Sebagaimana disebutkan dalam surat al-Maidah ayat 57-58 yang artinya "Hai orang-orang yang beriman, janganlah kamu mengambil jadi pemimpinmu orang-orang yang membuat agamamu jadi buah ejekan dan permainan, (yaitu) diantara orang-orang yang telah diberi kitab sebelummu, dan orang-orang yang kafir (orang-orang musyrik). Dan bertakwalah kepada Allah, jika kamu betul-betul orang yang beriman dan Apabila kamu menyeru (mereka) untuk mengerjakan (shalat), mereka menjadikanya buah ejekan dan permainan. Yang demikian itu adalah karena mereka benar-benar kaum yang tidak mau mempergunakan akal." (Muhammad Umar Jiau Al-Haq 2009)

Kedua, larangan mengambil orang-orang kafir sebagai pelindung dan penolong. Allah melarang orang-orang yang beriman untuk mengambil orang-orang kafir yang suka mengejek dan suka mempermainkan agama Islam, untuk menjadi teman akrab, pelindung dan penolong, baik orang-orang kafir asli, seperti penyembah api, berhala dan sebagainya, maupun yang tidak asli seperti ahli kitab, yaitu orang-orang yahudi dan nasrani. Selanjutnya Allah memerintahkan orang-orang mukmin bertakwa, menjauhi larangan-Nya yaitu berteman akrab dengan orang-orang kafir, karena tidak ada alas an lagi bagi orang-orang yang benar-benar beriman untuk berteman akrab atau tolong menolong dengan orangorang kafir yang mengejek dan mempermainkan agama Islam.

Ketiga, hadits ahad sebagai hujjah dalam aqidah dan hukum. Hadits ahad adalah hadits yang periwayatnya tidak mencapai jumlah orang banyak, sehingga tidak mencapai derajat mutawatir. Hadits ahad, menurut muhaditsin dan jumhur ulama wajib diamalkan apabila memenuhi syarat kesahihan dan diterimanya hadits itu. Setiap muslim wajib untuk mengimani setiap hadits yang tetap (shahih) dari Rasulullah Saw. selama mengandung syarat-syarat shahih dab diterima bagi ahli ilmu tanpa ada cela dalam sanad ataupun matanya meskipun nilainya ahad baik dalam hal aqidah maupun hukum.

Keempat, bahaya kemusyrikan dan faktor kesesatanya. Imam Ath-Thabari menjelaskan, Allah tidak akan mengampuni kekafiran dan penyekutuan terhadap-Nya, dan Dia mengampuni dosa-dosa selain itu terhadap hamba-Nya yang Dia kehendaki. Surat an-Nisa' 
ayat 48 menjelaskan bahwa setiap pelaku dosa besar tergantung kehendak Allah, apabila Dia menghendaki, maka mengampuni dan bula menghendaki (lain), maka menyiksanya, selama dosa besarnya bukan syirik kepada Allah. Diantara hal-hal yang menyebabkan kemusyrikan adalah adalah sikap kultus (mendewa-dewakan syaikhya, ulamanya, pemimpinya, hawa nafsu, tradisi dan paham yang bertentangan dengan hokum Allah, dan lain-lain). Selain itu taqlid dan mengikuti tradisi nenek moyang juga dapat menimbulkan kemusyrikan.

Kelima, taat kepada ulil amri. Ali bin Abi Thalhah berkata dari Ibnu abbas bahwa "ulil amri diantara kalian adalah ahli fiqh dan ahli agama". Demikian pula menurut Atha', Hasan Al-Bashri dan Abu Al-'Aliyah berkata bahwa "ulil amri diantara kalian adalah ulama”. Yang jelas bahwa ulil amri itu umum, mencakup setiap pemegang urusan, baik umara maupun ulama. Sebagaimana terdapat dalam surat Al-Maidah ayat 63 yang artinya "Mengapa orangorang alim mereka dan pendeta-pendeta mereka tidak melarang mereka mengucapkan perkataan bohong dan memakan yang haram?. Sesungguhnya amat buruk apa yang telah mereka kerjakan itu". Demikian juga dalam surat An-Nahl ayat 43 menyebutkan "Dan kami tidak mengutus sebelummu, kecuali orang-orang lelaki yang kami beri wahyu kepada mereka, maka bertanyalah kepada orang yang mempunyai pengetahuan jika kamu tidak mengetahui". Jadi ketaatan itu hanya dalam hal yang ma'ruf dan benar.

\section{Kesimpulan}

Bentuk-bentuk ajaran Minardi Mursyid pada kegiatan LPPA Tauhid adalah: pertama, tulisan di sebuah situs yang berjudul "Masyarakat Manusia di Planet Luar Bumi”. Kedua, menulis buku berjudul "Al Quran sebagai Rahmatan lil 'Alamin". Ketiga, menulis buku berjudul "Benarkah Mendalami Al Quran Itu Ingkar Sunnah. Keempat, makalah Minardi Mursyid yang berjudul "Bimbingan Untuk Bertahajud”. Dalam semua tulisanya tersebut semuanya memakai ayat-ayat al-Qur'an sebagai dalil. Selain buku dan makalah diatas Minardi Mursyid juga mengajarkan beberapa ajaranya, diantaranya adalah: a). Minardi Mursyid dalam menerjemahkan Al Qur'an tidak sesuai dengan kaidah -kaidah bahasa Arab dan ilmu tafsir, seperti : kata "zaighun" Qur'an surat Ali Imron ayat 7 yang artinya sesat atau kesesatan, dia artikan dengan "inisiatif”. Sebagaimana yang dia ungkapkan "adapun orang yang dalam qolbunya condong (inisiatif)" (Terjemahan Al Qur’an versi Tadabbur : Terbitan LPPA Tauhid

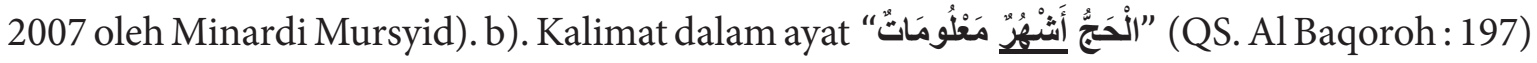
dijelaskan oleh Minardi Mursyid bahwa "Haji itu pada bulan-bulan tertentu yaitu, Muharrom,

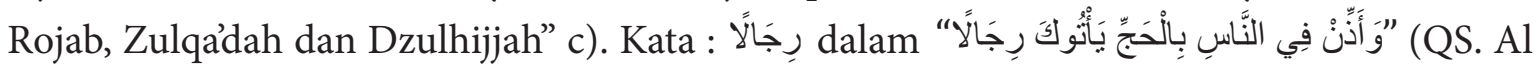
Hajj : 27) yang berarti dengan berjalan kaki, dia artikan dengan "berlaki-laki" (Terjemahan Al Qur’an versi Tadabbur : Terbitan LPPA Tauhid 2007 oleh Minardi Mursyid). d). Kata:

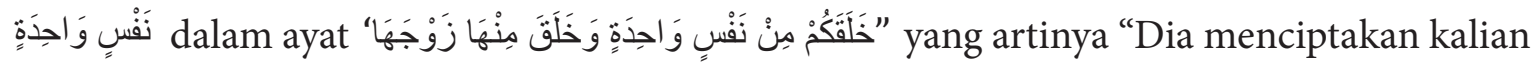


dari diri yang satu (Adam) dan Dia ciptakan darinya isterinya (Hawa), ditafsirkan oleh Minardi Mursyid bahwa manusia pertama adalah wanita. Dan masih banyak lagi keganjilan keganjilan dalam menafsirkan ayat ayat Al Qur'an. Minardi Mursyid mengajarkan bahwa sumber hukum Islam itu hanya Al Qur’an, karena selain Al Qur’an bukan wahyu.

Korelasi aliran inkar as-sunnah dengan aliran sesat di Indonesia adalah bahwa inkar assunnah termasuk aliran sesat, karena golongan inkar as-sunnah tidak menggunakan sunnah sebagai sumber hukum. Mereka hanya menggunakan al-Qur'an saja dan menafsirkanya sesuai dengan tafsiranya sendiri. Padahal standar ukuran kebenaran dalam islam adalah al-Qur'an, as-Sunnah, rukun iman dan rukun islam. Karena al-Qur'an tidak ada keraguan walaupun berbeda faham dalam penafsiranya, namun semua tidak meragukan kebenaran al-Qur'an, tidak ada kekeliruan, dijamin kemurnianya, dan tidak ada pertentangan. Sedang sunnah adalah perkataan, perbuatan serta ketetapan Nabi Saw. yang berupa qauliyah, af'aliyah dan taqririyah. Selanjutnya rukun iman dan rukun islam, dimana dalam rukun iman kita harus percaya kepada Rasul Allah. Kepercayaan tersebut kita realisasikan melalui mengikuti apa yang disunnahkan oleh Rasul Saw.

\section{Referensi}

Abd. al-Wahhab Khalaf, 1996. "Ilmu Usul al-Fiqh, teij. Masdar Helmy, Bandung: Gema Risalah Press

Azami, M.M, Dirasat fi al-Hadits al-Nabawi wa Tarikh Tadwinih, Beirut: al-Maktabah alIslami.

Ismail, M. Syuhudil, 1994. Hadits Nabi yang Tekstual dan Kontekstual: Telaah Ma 'ani alHadits Tentang ajaran Islam uang Universal, Temporal dan Lokal, Jakarta; Bulan Bintang

Irsyadunnas, 2003. Inkar al-Sunnah: Sejarah Kemunculan dan Perkembanganya, Jumal studi Ilmu- Ilmu Al-Qur'an dan Hadits.

Ismail, M. Syuhudi, 1995 Hadits di mata Pembela, Pengingkar dan Pemalsunya, Jakarta: Gema Insani Press.

Khon, Abdul Majid, 2011. Pemikiran Modern dalam Sunnah; Pendekatan Ilmu Hadits, Jakarta: Kencana Prenada Media Group.

Yaqup, Ali Mustafa, 1996. Kritik Hadits, Jakarta: Pustaka Firdaus.

Muhammad Umar Jiau Al-Haq, 2009. Mencermati Aliran Sesat, Bandung: Pustaka Islamika.

Ibnu Qudamah Al-Maqdisi, 1997. Mukhtasar Minhajul Qashidin, Mansyuratul Maktabil Islami cet. III, terjemahan Kathur Suhardi, Jakarta: Pustaka Al-Kautsar.

Hartono Ahmad jaiz, 2002. Aliran dan paham sesat di Indonesia, Jakarta: Pustaka al-Kautsar.

Syeh Muhammad Ali Ash-Shabuni Ath-Thabari, Mukhtasar Tafsir Ath-Thabari jilid 1, Kairo: Darus Shabuni, 
Daud Rasyid, 2006. Sunnah di Bawah Ancaman: Dari Snouck Hugronje hingga Harus Nasution, Syamil: Bandung.

MM Azami, 2000. Hadits Nabi di Mata Pembela, Pengingkar dan Pemalsunya (Jakarta: Pustaka Setia.

Zufran Rahman, 1995. Sunnah Nabi Saw.sebagai sumber Hukum Islam (Jawaban terhadap Inkar As-Sunnah), cet. Ke 1, Jakarta: Pedoman Ilmu Jaya.

Ahmad Husnan, 1995. Gerakan Inkar as-Sunnah dan Jawabannya, Cet. Ke-3, Jakarta: Media Da'wah.

M. Hasbi As-Shiddieqy, 1980. Sejarah dan Pengantar Ilmu Hadist, Cet. Ke-6, Jakarta : Bulan Bintang.

Syaukânî, 1999. Irsyâd alFuhul ilâ Tahqî̀q al- $\underline{H} a q$ min 'Ilmi al-Ushûl, Juz 1, Beirut : Dâr alSya ab al-'Ilmîyah. 